\title{
Correction to: Binding of Brucella protein, Bp26, to select extracellular matrix molecules
}

\author{
Yasmin ElTahir ${ }^{*}$, Amna Al-Araimi ${ }^{1}$, Remya R. Nair ${ }^{1}$, Kaija J. Autio², Hongmin Tu², Jack C. Leo ${ }^{3,4}$,
} Waleed Al-Marzooqi ${ }^{1}$ and Eugene H. Johnson ${ }^{1}$

\section{Correction to: BMC Mol and Cell Biol https://doi.org/10.1186/s12860-019-0239-7}

Following publication of the original article [1], an error was reported in the tagging of Eugene $\mathrm{H}$. Johnson and Remya R. Nair in the author group. The tagging in the correction article has been fixed.

The current article [1] tagging is as follows:

Given Name: Eugene

Family Name: H. Johnson

Given Name: Remya

Family Name: R. Nair

The correct tagging should be:

Given Name: Eugene H.

Family Name: Johnson

Given Name: Remya R.

Family Name: Nair

\section{Author details}

${ }^{1}$ Department of Animal \& Veterinary Sciences, Sultan Qaboos University. College of Agricultural \& Marine Sciences, P.O.box 34. 123 Alkhod, Muscat, Sultanate of Oman. ${ }^{2}$ Faculty of Biochemistry and Molecular Medicine, University of Oulu, Fl-90014 Oulu, Finland. ${ }^{3}$ Section for Genetics and Evolutionary Biology, Department of Biosciences, University of Oslo, 0361 Oslo, Norway. ${ }^{4}$ Department of Biosciences, School of Science \& Technology, Nottingham Trent University, Nottingham NG1 4FQ, UK.
Published online: 18 March 2020

\section{Reference}

1. EITahir Y, Al-Araimi A, Nair RR, et al. Binding of Brucella protein, Bp26, to select extracellular matrix molecules. BMC Mol and Cell Biol. 2019;20:55 https://doi.org/10.1186/s12860-019-0239-7.

The original article can be found online at https://doi.org/10.1186/s12860019-0239-7

* Correspondence: yasmin@squ.edu.om

'Department of Animal \& Veterinary Sciences, Sultan Qaboos University.

College of Agricultural \& Marine Sciences, P.O.box 34. 123 Alkhod, Muscat, Sultanate of Oman

(c) The Author(s). 2020 Open Access This article is licensed under a Creative Commons Attribution 4.0 International License, which permits use, sharing, adaptation, distribution and reproduction in any medium or format, as long as you give appropriate credit to the original author(s) and the source, provide a link to the Creative Commons licence, and indicate if changes were made. The images or other third party material in this article are included in the article's Creative Commons licence, unless indicated otherwise in a credit line to the material. If material is not included in the article's Creative Commons licence and your intended use is not permitted by statutory regulation or exceeds the permitted use, you will need to obtain permission directly from the copyright holder. To view a copy of this licence, visit http://creativecommons.org/licenses/by/4.0/ The Creative Commons Public Domain Dedication waiver (http://creativecommons.org/publicdomain/zero/1.0/) applies to the data made available in this article, unless otherwise stated in a credit line to the data. 